\title{
Corporate Governance and Firm Performance: An Empirical Study from Indonesian Manufacturing Firms
}

\author{
Sri HERMUNINGSIH ${ }^{1}$, Hadri KUSUMA ${ }^{2}$, Rahma Anzalia CAHYARIFIDA ${ }^{3}$ \\ Received: August 01, 2020 Revised: September 30, 2020 Accepted: October 15, 2020
}

\begin{abstract}
The use of different proxies to measure good corporate governance (GCG) may be a probable cause of the mixed results. Therefore, the application of a new single measure to enhance comparable empirical studies is required. The purpose of this study is to examine the relationship between corporate governance and firm's performance. This study involved all manufacturing companies listed on the Indonesia Stock Exchange (IDX) from 2014 to 2016 through purposive sampling with specific criteria. out of 144 qualified companies, 110 companies could be processed because of completed data in the form of financial information from their financial statements during the research period. The data were obtained from the official websites of IDX. This study applies a new measure of the corporate governance: the efficiency of the GCG. The corporate governance is calculated by relating inputs of components of the corporate governance and outputs of sales, assets and firm equity capital. By using financial data from firms listed on the Indonesian Capital Market, this study finds that the corporate governance significantly improved firm's performance. More importantly, the study confirms and supports the new single measure of the GCG. This result is very important to avoid dealing with different indicators of the corporate governance.
\end{abstract}

Keywords: Corporate Governance, Financial Performance, Firm Size, Firm Age

JEL Classification Code: G38, G39, L25, L29

\section{Introduction}

According to Melawati et al. (2016), Indonesia is in the process of significant industrial development. It is indicated by a high level of company growth especially in manufacturing and service sectors. These companies in general have the intention to increase their performance in terms of maximizing values and stakeholders' welfare. Mishra and Mohanty (2014) stated that the fundamental point of the view of the good company performance may lead to high company values and attract investors and other

${ }^{1}$ First Author and Corresponding Author. Associate Professor, Department of Management, Universitas Sarjanawiyata Tamansiswa, Indonesia [Postal Address: Jalan Kusumanegara 121, Yogyakarta, Indonesia] Email: hermun_feust@yahoo.co.id

${ }^{2}$ Professor, School of Accounting, Universitas Islam Indonesia, Yogyakarta, Indonesia. Email: 883120104@uii.ac.id

${ }^{3}$ School of Accounting, Universitas Islam Indonesia, Yogyakarta, Indonesia. Email: rahmanzalia21@gmail

() Copyright: The Author(s)

This is an Open Access article distributed under the terms of the Creative Commons Attribution Non-Commercial License (https://creativecommons.org/licenses/by-nc/4.0/) which permits unrestricted non-commercial use, distribution, and reproduction in any medium, provided the original work is properly cited. potential users. On the other hand, bad company performance can lower its share value. Company's performance is also a result of company's formal efforts and reflects the efficiency and the effectiveness of company activities in a certain period (Kusuma \& Ayumardani, 2016). The company performance shows the credibility of a company to investors, customers, and general potential users. Firm's financial performance, for example, can indicate the accomplishment of firm's goal and serve as the basis for decision-making. The information about the financial performance is important for investors to decide whether they will keep or release their investment (Mursalim et al., 2017).

There have been previous studies examining the relationship between corporate governance and company performance (Drobetz, 2015; Jantadej \& Wattanatorn, 2020; Tsai \& Tung, 2014; Reddy et al., 2017). However, the results of those studies have been mixed. Mishra and Mohanty (2014) found that board of directors affects company financial performance, while Melawati et al. (2016) show the opposite result. Drobetz (2015) found that the board of commissioners positively affects company financial performance, while Melawati et al. (2016) showed the opposite finding. In terms of independent commissioners, 
Drobetz (2015) found this variable has a positive influence on the company financial performance, but Tertius and Christiawan (2015) showed the opposite results. Melawati et al. (2016) found that company size has a positive influence on company financial performance, but Tertius and Christiawan (2015) stated otherwise.

One of the probable reasons for this inconsistent result is due to the different proxies used when measuring the variables. Corporate governance (GCG), for example, was measured using board of commissioners, board of directors, independent commissioners, or company size. This different proxies of the corporate government make it difficult to interpret and conclude whether the governance improves firm's performance. Therefore, a single measurement is to improve the quality of the study and to improve research results by becoming more comparable. Larcker et al. (2006) further argue that the lack of consistent empirical results on the influence of corporate governance on the performance is due to the difficulty in adequately measuring corporate governance. This study examines the relationship between the corporate governance and company performance. However, this study uses a single measurement of the corporate governance. Following Lehmann et al. (2004), GCG is measured for its efficiency and calculated by connecting corporate governance components as the inputs and sale, asset, and company capitals as the outputs. This study employs a single unique technique called Data Envelopment Analysis (DEA) to measure corporate governance. Bauer et al. (1998) argued that efficient frontier approaches, such as the DEA model, seem to be superior compared to traditional measures.

\section{Theoretical Framework}

\subsection{Literature Review}

Maretha and Purwaningsih (2013) stated that performance reflects the success of an activity, program, or policy in accomplishing the target, goal, mission, and vision of an organization. Simply stated, company performance is a formal effort to evaluate the efficiency and effectiveness of company activities over a certain period. Company financial performance reflects the financial condition and the achievement of a company based on its financial report over a certain period. A financial report is issued periodically to be used by investors, creditors, prospective creditors, managers, employees, government, and society for their own purposes. For example, information on company performance is important to investors in considering either keeping their investment in a company or finding other alternatives. In addition, such information shows the credibility of a company to potential users. Mishra and Mohanty (2014) also stated from the fundamental point of view that good company performance leads to high company value and attracts investors, increasing the share value.

Previous studies have examined factors influencing company performance (Arora \& Sharma, 2016; Drobetz, 2015; Mishra \& Mohanty, 2014; Emile, 2014; Tsai \& Tung, 2014; Hosseinyan et al., 2015; Fernndez-Gago et al., 2016; Gherghina, 2015). Referring to those studies, key factors improving the company performance include board of commissioners, board of directors, independent commissioners, company size, corporate social responsibility (CSR), Chief Executive Officer (CEO) duality, block holders, managerial ownership, legal compliance, leverage, nonperforming loan (NPL), profitability, family management, and board meeting. The following section describes these important and successful drivers. This section describes some important factors enhancing firm's performance and the results of prior studies.

A board of commissioners is an organ responsible for supervising according to a company's article of association and providing suggestions to directors (Law of the Republic of Indonesia Number 24 of 2007 Concerning Limited Liability Company, 2007). Tertius and Christiawan (2015) stated that a board of commissioners influences company by supervising a company so that it is in accordance with its owners' interests in increasing return and performance. Drobetz (2015) and Arora and Sharma (2016) found that good corporate governance manifested in the size of a board of commissioners has a positive influence on company performance. However, Melawati et al. (2016) found the opposite result.

A board of directors is an organ fully responsible for operational and managerial matters of a company (Melawati et al., 2016). According to them, the size of a board of directors affects company performance because the board sets policies and strategies for company resources both in short and long terms. Mishra and Mohanty (2014) found that the size of a board of directors affected company performance. However, Melawati et al. (2016) found that the opposite is true.

Independent commissioners are members of a board of commissioners with no financial, managerial, shareholding, and family relationships with other commissioners, directors, and controlling shareholders or banks that may influence their ability to act independently (Law of the Republic of Indonesia Number 24 of 2007 Concerning Limited Liability Company, 2007). Independent commissioners influence company performance because they are responsible for independent assessment of strategies, performance, and resources of a company (Tertius \& Christiawan, 2015). Drobetz (2015) found that the size of independent commissioners positively influenced company performance. However, Tertius and Christiawan (2015) found that the size of independent commissioners negatively influenced company performance. 
The company size is the scale used to measure the size of a company (Tertius \& Christiawan, 2015). Company size influences company performance because a big company has more operational activities that may result in big profit and increase company performance. Melawati et al. (2016) stated that company size positively influences company performance, but Tertius and Christiawan (2015) reached the opposite conclusion.

Corporate Social Responsibility (CSR) is an effort to share a company's wealth to minimize negative impacts and maximize positive impacts in economic, social, and environmental activities (Jahid et al., 2020). CSR influences company performance in a way that more CSR disclosure items lead to a better performance. Satria (2014) asserted that CSR has an influence on company performance in the long run because it leads to the increase of the welfare of investors, employees, and other stakeholders. However, Melawati et al. (2016) found the opposite result.

CEO duality means that a person holds two positions as a chairman of the board and a CEO (Emile et al., 2014). CEO duality affects company performance because of the conflict of interest in it. Emile et al. (2014) stated that CEO duality has an influence on company performance, but Arora and Sharma (2016) conclude otherwise.

Blockholder is an investor with a significant public share ownership of $1 \%$ to $5 \%$ (Reddy et al., 2017). According to Emile et al. (2014), blockholders have an influence on company performance because they reflect unpublished share ratio that is not sold, but concentrated and blocked by certain shareholders. Emile et al. (2014) and Reddy et al. (2017) found that blockholders positively influence company performance.

Managerial ownership is the number of shares owned by owners, executive board members, and managers in a company (Tertius \& Christiawan, 2010). Managerial ownership influences company performance because it motivates the management to work carefully in increasing company performance (Tertius \& Christiawan, 2015). This is supported by Tertius and Christiawan (2015) who found that managerial ownership influences company performance.

Legal compliance refers to a fair and transparent legal system to comply with to gain foreign investors' trust. Legal regulations and the quality of law enforcement regarding investor protection have an influence on the size of stock market (Reddy et al., 2017). Legal compliance affects company performance because poor law enforcement makes regulations ineffective, resulting in fraud affecting the company performance. Reddy et al. (2017) found that legal compliance does not influence company performance.

Family management means that family members hold the positions of board of directors (Chief Executive Officer or Chief Financial Officer) or core management. Reddy et al. (2017) stated that family management tends to increase company performance, and they found that condition in their study.

A board meeting is a formal director meeting conducted regularly to consider policies and main problems (Arora \& Sharma, 2016). They stated that a board meeting influences company performance because it is within collective responsibility of all directors involved in it.

Non Performing Loan (NPL) is a ratio showing the ability of bank management in managing problematic loan (Mustofa \& Haryanto, 2014). According to Mustofa and Haryanto (2014), Non Performing Loan influences company performance in banking sectors because higher NPL ratio leads to worse quality of loans, resulting in increasing problematic loan and decreasing company performance.

Net Interest Margin (NIM) is a risk due to changing market conditions that may cause a loss for a bank (Mustofa $\&$ Haryanto, 2014). NIM influences company performance because higher NIM will increase income and prevent a company from trouble. They also proved that NIM affects company performance.

BOPO ratio is an index between operational cost and operational income to measure the level of efficiency and ability in operational activities (Mustofa \& Haryanto, 2014). According to them, the smaller BOPO ratio, the more efficient a company in running its operation. They proved that BOPO influences company performance.

Leverage is a ratio to measure the quality of a company capital structure. According to Vijayakumaran and Vijayakumaran (2019), leverage is a financial resource of a company from third parties other than investors, and it explains how a company funds its financial operation through the use of debt (Sumani \& Roziq, 2020). Leverage influences company financial performance whereby lower leverage means lower financial risks and increasing profit. Hariyadi (2014) found that leverage does not affect company financial performance.

Capital Adequacy Ratio (CAR) is a performance ratio to measure capital sufficiency for supporting assets containing or causing risks, such as given debts (Mustofa \& Haryanto, 2014). According to the Indonesian central bank, a healthy bank has a minimum CAR of $8 \%$. CAR affects company performance because a company can identify capitals to anticipate assets with risks that can influence company performance. Mustofa and Haryanto (2014) proved that CAR has an influence on company performance.

As indicated above, several studies showed consistent results. Managerial ownership (Tertius \& Christiawan, 2015), blockholders (Emile, 2014; Reddy et al., 2017), family management (Reddy et al., 2017), board meeting (Arora \& Sharma, 2016), and NPL, NIM, BOPO, and CAR as the proxies for corporate governance (Mustofa \& Haryanto, 2014) were found to have a positive influence on company performance. 
Other studies showed inconsistent results regarding several variables, namely, board of commissioners (Drobetz, 2015; Arora \& Sharma, 2016), board of directors (Mishra \& Mohanty, 2014), independent commissioners (Drobetz, 2015), company size (Tertius \& Christiawan, 2015), leverage (Hariyadi, 2014), and corporate social responsibility (CSR) (Satria, 2014) stated that CSR does not influence company performance because Law No. 40 Year 2007 on Limited Company requires all companies to conduct CSR and gives sanctions for any companies that do not comply with the law. It means that investors do not consider CSR disclosure.

Satria (2014) found that there is subjectivity in CSR measurement due to the lack of requirements or guidance for CSR conduct, which that leads to different results in different studies. In addition, the limitation of the previous studies conducted by Hosseinyan et al. (2015), Satria (2014), and Tertius and Christiawan (2015)was the use of ROA as a single measurement for financial performance. ROA is only supposed to measure a company ability to gain profit.

Melawati et al. (2016) suggested using other variables in future studies to find a standard model of company performance influence in the form of external control structures such as stock market, financial market, regulator, and other professions. Meanwhile, Drobetz (2015) suggested including the influence of global financial crisis, new measurement tools, methods, and variables for corporate governance.

Based on the limitation and suggestion from the previous studies, this study focused on the inconsistent variables that need to be reexamined, such as board of commissioners, board of directors, independent commissioners, leverage, and company size. In addition, based on Drobetz's (2015) suggestion, company size was also added as a variable.

\subsection{Hypothesis Development}

The following part describes the influence of each componentofthecorporategovernanceonthe firmperformance. The components are size of board of commissioners, board of directors, independent commissioners, audit committee and institutional ownership.

According to Indonesian Law No. 40 Year 2007 on the Limited Company, a board of commissioners is a part of an organization responsible for supervising according to a company's article of association and providing suggestions to directors. A board of commissioners also supervises the process off financial report preparation to minimize manipulation and management's opportunistic behaviors. Tertius and Christiawan (2015) stated that a large board of commissioners can minimize manipulation and increase access to various external resources that can increase company performance. A large board of commissioners provides various expertise, knowledge, and skills. Good company financial performance can increase investors' trust to invest in a company. Drobetz (2015), Arora and Sharma (2016), and Adestian and Nuswantoro (2014) also found that the size of a board of commissioners has a positive influence on good corporate governance and company financial performance.

According to Melawati et al. (2016), a board of directors is responsible for all operational and managerial activities of a company. According to government of Indonesia, a board of directors must be able to make decisions effectively, properly, and quickly and act independently (National Committee on Governance Policy, 2006). Thus, the size of a board of directors influences how quick a decision is made because of the good coordination among directors. Therefore, the size of a board of directors is an important part of Corporate Governance for defining company performance. Mishra and Mohanty (2014) found that this variable has a positive influence on company financial performance.

Independent commissioners are members of a board of commissioners with no financial, managerial, shareholding, and family relationships with other commissioners, directors, and controlling shareholders or banks that may influence their ability to act independently. Independent commissioners have a controlling role in evaluating managerial decisions so that they can monitor a company closer and reduce bad managerial performance, and thus increasing ROA (Tertius \& Christiawan, 2015). Of the previous studies, Tertius and Christiawan (2015) found that the bigger the number of independent commissioners is, the less manipulation can be done by a company management, resulting in increasing company financial performance. Drobetz (2015) also found that the size of independent commissioners positively influenced company financial performance.

An audit committee is responsible for assisting a board of commissioners in ensuring that a company financial report is presented fairly according to the valid accounting principles, that the internal control structure is implemented well, that both internal and external audits are conducted in accordance with the valid standard, and that audit findings are followed up by the management (Adestian \& Nuswantoro, 2014). An audit committee is influential to company performance because it monitors the process of financial reporting. They stated that the size of an audit committee influences the company financial performance since all of the committee members review a company's accounting policies, assess its internal control, and review its external reporting system and its compliance with regulations. Adestian and Nuswantoro (2014) also proved it in their study.

Institutional ownership refers to shares owned by institutions like insurance companies, banks, investment companies, and other institutions (Susanti \& Mildawati, 2014). According to them, institutional ownership is the percentage of shares owned by external parties. They stated that larger institutional ownership percentage results in more intense supervision by institutional investors, and thus preventing opportunistic managerial behaviors. Susanti 
and Mildawati, (2014) further found that large institutional ownership percentage leads to the increasing company value and better company financial performance.

Therefore, the hypothesis of this study was formulated as follow:

H1: Good corporate governance positively affects company's financial performance.

\section{Research Method}

This study involved all manufacturing companies listed on the Indonesia Stock Exchange (IDX) from 2014 to 2016, and the samples were obtained through purposive sampling with the following criteria:

1. Having published audited financial statement in Rupiah (IDR) as the currency.

2. Listed in IDX before the research period (January 1, 2013 at the latest) and not delisted during the research period.

3. Able to provide required financial statements and company data during the research period.

With those criteria, there were 144 qualified companies. However, 110 companies could be processed because of completed data in the form of financial information from their financial statements during the research period. The data were obtained from the official websites of IDX: www. idx.co.id and www.sahamok.com.

To achieve the goal of the research, this study followed a two-step procedure. First, this study calculated a single measure of the corporate governance using formula 1.

$$
\text { CGEff }=\frac{\sum_{\mathrm{i}=1}^{\mathrm{m}} \mathrm{uy}}{\sum_{\mathrm{j}=1}^{\mathrm{n}} \mathrm{vx}}
$$

CGEff is corporate governance efficiency. $u$ is output and $y$ is the number of output $i$ of a manufacturing industry; $v$ is input and $\mathrm{x}$ is the number of input $\mathrm{j}$. The indicators of corporate governance input are board of commissioners, board of directors, independent commissioners, audit committee, and institutional ownership. Sale, asset and equity of the firm's output of the efficiency. This study used EMS (Efficiency Measurement Systems) software to calculate the efficiency of the participating companies annually.

Second, the result of the corporate governance efficiency included in the regression analysis is for modeling the relationship between independent variables and the firm's performance. This study implements the technique called generalized linear models (GLM). According to Nelder and Wedderburn (1972), generalized linear models acted as the extension of the linear regression model with the assumption that the predictor had a linear effect but without the assumption of a certain distribution of the response. Therefore, the general linear model is used to avoid extreme data, classical assumption and abnormal data if using the technique of ordinary least square. This study operates the GLM technique of equation 2. CGEff $(\beta 1)$ coefficient of the equation is expected to have a positive sign and significance.

$$
\begin{array}{ll}
\mathrm{Y}=\beta_{1} \text { CGEff }+\beta_{2} \mathrm{UP}+\beta_{3} \mathrm{SIZE}+\beta_{4} \mathrm{DER}+3 \\
\mathrm{Y}= & \text { Company financial performance measured by } \\
& \text { return on asset (ROA) } \\
\beta_{1-4}= & \text { Regression coefficients } \\
\mathrm{CGeff}= & \text { corporate governance efficiency } \\
\mathrm{UP} & =\text { Company age } \\
\mathrm{SIZE}= & \text { Company size } \\
\mathrm{DER}= & \text { Leverage (debt to equity ratio) } \\
3 & =
\end{array}
$$

\section{Results and Discussion}

This section presents descriptive data, correlation among variables, and result of hypothesis testing. It is followed by the discussion and interpretation of the hypothesis test, and presentation of other results. Descriptive statistics was carried out to describe the data in term of mean (average), median, maximum and minimum value, and standard deviation. Table 1 shows the results of the descriptive data for the variables of good corporate governance, company age, leverage, company size, and company financial performance.

Table 1: Descriptive Statistic Data

\begin{tabular}{|l|c|c|c|c|c|}
\hline Measures & DER & CGeff & ROA & SIZE & UP \\
\hline Mean & 0.469124 & 0.153349 & 0.249726 & 7.260195 & 39.09091 \\
\hline Median & 0.803317 & 0.027050 & 0.039447 & 7.053548 & 39.00000 \\
\hline Maximum & 22.46110 & 1.000000 & 63.15105 & 12.30612 & 103.0000 \\
\hline Minimum & -225.0448 & 0.000100 & -0.548466 & 3.295837 & 5.000000 \\
\hline Std. Dev & 12.65540 & 0.293835 & 3.475285 & 1.544942 & 17.18797 \\
\hline Skewness & -17.19866 & 2.271536 & 18.04943 & 0.422149 & 1.328236 \\
\hline Kurtosis & 307.4485 & 6.629395 & 327.1897 & 3.418928 & 5.720583 \\
\hline
\end{tabular}


Table 2: Correlation among Variables

\begin{tabular}{|l|c|c|c|c|c|}
\hline VARIABLES & DER & GCG & ROA & SIZE & UP \\
\hline DER & 1.000000 & & & & \\
\hline CGeff & 0.018840 & 1.000000 & & & \\
\hline ROA & 0.005097 & 0.162762 & 1.000000 & & \\
\hline SIZE & 0.124630 & 0.261166 & -0.071273 & 1.000000 & \\
\hline UP & 0.029355 & 0.241682 & 0.017690 & 0.172154 & 1.000000 \\
\hline
\end{tabular}

Table 3: Result Hypothesis Testing Coefficients (Standard Error)

\begin{tabular}{|l|c|}
\hline \multicolumn{1}{|c|}{ Variable } & Coefficient \\
\hline & 0.000589 \\
DER & $(0.000176)^{*}$ \\
\hline & 7.332410 \\
CGEFF & $(1.338655)^{*}$ \\
\hline & -0.063112 \\
SIZE & $(0.010773)^{*}$ \\
\hline & 0.008961 \\
UP & $(0.001815)^{*}$ \\
\hline * Significant at 1\% level & \\
\hline
\end{tabular}

Correlation is a tool to measure a linear relationship between two variables. Table 2 shows the result of the correlation analysis. Table 2 shows that DER had a positive correlation with CGEFF with the value of 0.018840 , ROA with the value of 0.005097 , SIZE with the value of 0.124630 , and UP with the value of 0.029355 . GCG had a positive correlation with ROA, with the value of 0.162762 , SIZE with the value of 0.261166 , and UP with the value of 0.241682 . ROA had a positive correlation with UP, with the value of 0.017690 . SIZE had a positive correlation with UP with the value of 0.172154 . There was a negative correlation between ROA and SIZE with the value of -0.071273 .

To test the hypothesis, this study operates equation 2 using the techniques of generalized linear model (GLM). The study removes the intercept from equation 2 because it was not significant. Table 3 shows the result of hypothesis testing.

As expected, Table 3 shows that good corporate governance (CGeff) had the coefficient value of 7.332410. In addition, CGeff had the z-statistic value of 5.477477 and is significant at $1 \%$ level. This result can be interpreted that good corporate governance had a positive and significant influence on the company's financial performance, and thus the hypothesis is supported. In conclusion, the correct implementation of the good corporate governance increases company's financial performance.

The agency theory explains corporate governance in a company. According to Jensen and Meckling (1976), the agency theory is a contract between a manager (agent) and an owner (principal) for a service for the interest own the owner that includes delegating power and decision-making. Different interests of the manager and the owner result in information asymmetry and agency conflicts. The owners may want profits in terms of dividend from the investment, while the manager may prioritize their individual interests. With good corporate governance, it is expected that there will be less agency conflicts and company performance will improve. The result of this study supports this expectation.

This finding may draw some interpretations. The significant relationship between the corporate governance and company performance may imply that good corporate governance is related to independent commissioners due to the absence of financial, organizational, share holding, and family relationships with other commissioners, directors, shareholders, and banks that may affect their ability to act independently. Therefore, independent commissioners supervised directors' performance to avoid information asymmetry.

According to the agency theory, a board of commissioners has a role to improve good corporate governance. A large board of commissioners consists of various skills, knowledge, and expertise. Tertius and Christiawan (2015) stated that a board of commissioners minimizes manipulation that can reduce company financial performance and increases the access to external resources that can improve company performance. Good company financial performance can encourage investors to invest their money on the company.

A board of directors also plays an important role in corporate governance mechanism. A board of directors should be able to make decisions effectively, appropriately, quickly, and independently. Thus, the number of a board of directors' members is influential to the decision-making process for improving company performance.

Audit committee is responsible for helping a board of commissioners ensure that a financial report is presented fairly according to the acceptable accounting principles, that company internal control structure is implemented well, that internal and external audits are conducted according to the valid audit standard, and that the findings are implemented by the management (Adestian \& Nuswantoro, 2014). Audit 
committee monitors the financial reporting process and thus influences company performance.

Institutional ownership is also an important part of corporate governance for improving company performance. Christina and Ekawati (2011) stated that larger institutional ownership percentage results in more intense supervision by institutional investors, and thus preventing opportunistic managerial behaviors. Susanti and Mildawati (2014) found that large institutional ownership percentage leads to the increasing company value and better company financial performance.

Table 3 shows that all control variables significantly influence company performance. First, company age (UP) has the coefficient value of 0.008961 , showing the significant influence of the variable on company financial performance. Second, leverage (DER) has the coefficient value of 0.000589 and $z$-statistic value of 3.337462, showing that more leverage increases company financial performance. Finally, company size is $-0,063112$. It means that industrial company characteristics negatively and significantly influence company financial performance: the bigger the company size, the worse the company financial performance.

\section{Conclusion and Implication}

Previous studies on the relationship between corporate governance and company financial performance showed inconsistent results. This is probably due to different measures of corporate governance used by those studies. This study analyzed such relationship by using corporate governance efficiency as a single measure. The result shows that good corporate governance significantly improves company's financial performance. Other results also show that all control variables influenced company's financial performance.

This finding suggests that corporate governance efficiency as a measure of corporate governance can be used for describing the implementation of good corporate governance in a company, with all of its indicators as the input. Thus, future studies can use corporate governance efficiency as a single measure to improve the quality research on the corporate governance. This measure can enhance comparable results and avoid different indicators of the corporate governance. The significant relationship between corporate governance and the company performance also suggests that firms should implement five principles of corporate governance, namely, transparency, accountability, responsibility, independency, and fairness, to evaluate and improve their performance. As for investors and potential investors, they should further consider the implementation of those principles in a targeted company before starting their investments.

\section{References}

Adestian, Y., \& Nuswantoro, D. (2014). The Influence of the Board of Commissioners, the Board of Directors, the Independent Commissioner, the Audit Committee and the Size of the Company on the Performance of Banking Companies Listed in Bei in 2012-2014 (Indonesian), Thesis, Universitas Dian Nuswantoro. http://eprints.dinus.ac.id/17262/

Arora, A., \& Sharma, C. (2016). Corporate governance and firm performance in developing countries: evidence from India. Corporate Governance: The International Journal of Business in Society, 16(2), 420-436. https://doi.org/10.1108/CG-012016-0018

Bauer, P. W., Berger, A. N., Ferrier, G. D., \& Humphrey, D. B. (1998). Consistency Conditions for Regulatory Analysis of Financial Institutions: A Comparison of Frontier Efficiency Methods. Journal of Economics and Business, 50(2), 85-114. https://doi.org/10.1016/S0148-6195(97)00072-6

Christina, Y. T., \& Ekawati, E. (2011). Excess Cash Holdings and Institutional Ownership Of Manufacturing Companies Listed on the Indonesian Stock Exchange (Indonesian)dx. Matrik: Jurnal Manajemen, Strategi Bisnis \& Kewirausahaan, 8(1), $1-10$.

Drobetz, W., \& Drobetz, W. (2015). The Impact of Corporate Governance on Firm Performance: Evidence from Bahrain Bourse. Finance, 6(6), 1-11. https://doi.org/10.5539/ijef. v6n6p 1

Emile, R., Ragab, A., \& Kyaw, A. (2014). The Effect of Corporate Governance on Firm Performance: Evidence from Egypt. Asian Economic and Financial Review, 4(12), 1865-1877.

Fernndez-Gago, R., Cabeza-Garca, L., \& Nieto, M. (2016). Corporate social responsibility, board of directors, and firm performance: an analysis of their relationships. Review of Managerial Science, 10(1), 85-104. https://doi.org/10.1007/ s11846-014-0141-9

Gherghina, Ş. C. (2015). Corporate Governance Ratings and Firm Value: Empirical Evidence from the Bucharest Stock Exchange. International Journal of Economics and Financial Issues, 5(1), 97-110.

Hariyadi, R. (2014). The Influence of Corporate Social Responsibility on Company Financial Performance with Financial Leverage and Company Size as Moderation Variables (Empirical Study of Public Manufacturing Companies Listed on the Indonesia Stock Exchange in 2006-2009) (Indonesian), Thesis, http://eprints.ums.ac.id/30625/

Hosseinyan, N., Hashim, F., \& Isa, S. M. (2015). The Role of Corporate Governance on the Relationship Between Related Party Transaction and Firm Value. Working Paper. Available at SSRN: https://ssrn.com/abstract=1539808 or http://dx.doi. org/10.2139/ssrn. 1539808

Law of the Republic of Indonesia Number 24 of 2007 Concerning Limited Liability Company, Minister of Justice and Human Rights 1 (2007). https://www.extractiveshub.org/servefile/ getFile/id/6883 
Jahid, M. A., Rashid, M. H. U., Hossain, S. Z., Haryono, S., \& Jatmiko, B. (2020). Impact of corporate governance mechanisms on corporate social responsibility disclosure of publicly-listed banks in Bangladesh. Journal of Asian Finance, Economics and Business, 7(6), 61-71. https://doi.org/10.13106/ jafeb.2020.vol7.no6.061

Jantadej, K., \& Wattanatorn, W. (2020). The Effect of Corporate Governance on the Cost of Debt: Evidence from Thailand. Journal of Asian Finance, Economics and Business, 7(9), 283-291. https://doi.org/10.13106/jafeb.2020.vol7.no9.283

Jensen, M. C., \& Meckling, W. H. (1976). Theory of the Firm: Managerial.Journal of FinancialEconomics, 3, 305-360. https:// doi.org/http://dx.doi.org/10.1016/0304-405X(76)90026-X

Kusuma, H., \& Ayumardani, A. (2016). the Corporate Governance Efficiency and Islamic Bank Performance: an Indonesian Evidence. Polish Journal of Management Studies, 13(1), 111120. https://doi.org/10.17512/pjms.2016.13.1.11

Larcker, D. F., Richardson, S. A., \& Tuna, İ. (2006). Corporate Governance, Accounting Outcomes, and Organizational Performance Corporate Governance, Accounting Outcomes, and Organizational Performance. The Accounting Review, 82(4), 963-1008.

Lehmann, E., Warning, S., \& Weigand, J. (2004). Governance structures, multidimensional efficiency and firm profitability. Journal of Management and Governance, 8(3), 279-304. https://doi.org/10.1007/s10997-004-1116-z

Maretha, N., \& Purwaningsih, A. (2013). Effect of Good Corporate Governance Implementation on Company Performance, with Asset Composition and Company Size as Control Variables (Indonesian). Modus, 25(2), 153-169.

Melawati, Nurlaela, S., \& Wahyuningsih, E. M. (2016). The Effect of Good Corporate Governance, Corporate Social Responsibility, and Company Size on Company Performance (Indonesian). http://hdl.handle.net/11617/7166

Mishra, S., \& Mohanty, P. (2014). Corporate governance as a value driver for firm performance: evidence from India. Corporate Governance: The International Journal of Business in Society, 14(2), 265-280. https://doi.org/10.1108/CG-12-2012-0089

Mursalim, Mallisa, M., \& Kusuma, H. (2017). Capital Structure Determinants and Firms' Performance: Empirical Evidence from Thailand, Indonesia and Malaysia. Polish Journal of Management Studies, 16(1), 154-164. https://doi.org/10.17512/ pjms.2017.16.1.13

Mustofa, M. I., \& Haryanto, M. (2014). Analysis of The Effect of Risk, Efficiency Level, and Good Corporate Governance on Banking Financial Performance (Approaches of Some
Components of Risk Based Bank Rating Methods Sebi 13/24 / Dpnp / 2011) (Indonesian). Jurnal Studi Manajemen \& Organisasi, 11(2), 126-142. https://doi.org/https://doi. org/10.14710/jsmo.v11i2.13168

National Committee on Governance Policy. (2006). General Guidelines on Good Corporate Governance in Indonesia. www. governance-indonesia.or.id

Nelder, J. A., \& Wedderburn, R. W. M. (1972). Generalized Linear Models. Journal of the Royal Statistical Society, 135(3), 370-384.

Reddy, K., Wellalage, N. H., \& Wang, Z. (2017). Corporate Governance Practices of Family Firms in Europe and Firm Financial Performance. https://doi.org/http://dx.doi. org/10.2139/ssrn.2914735

Satria, D. (2014). The Influence of Corporate Social Responsibility (Csr) on Company Financial Performance (Empirical Study of Manufacturing Companies Listed on the Indonesia Stock Exchange in 2011) (Indonesian). Diponegoro Journal of Accounting, 3(1), 225-230.

Sumani, S., \& Roziq, A. (2020). Reciprocal Capital Structure and Liquidity Policy: Implementation of Corporate Governance toward Corporate Performance. Journal of Asian Finance, Economics and Business 7(9), 85-93. https://doi.org/10.13106/ jafeb.2020.vol7.no9.085

Susanti, R., \& Mildawati, T. (2014). The Effect of Management Ownership, Institutional Ownership and Corporate Social Responsibility on Company Value (Indonesian). Jurnal Ilmu \& Riset Akuntansi, 3(1), 1-18. https://doi. org/10.1080/17450140600679883

Tertius, M. A., \& Christiawan, Y. J. (2010). The Effect of Good Corporate Governance on Company Performance in the Financial Sector (Indonesian). Majalah Ilmiah Informatika, $3(2), 47-60$.

Tsai, M.-T., \& Tung, W.-H. (2014). Corporate governance, resources, FDI commitment and firm performance. Chinese Management Studies, 8(3), 313-332. https://doi.org/10.1108/ CMS-08-2012-0118

Vijayakumaran, S., \& Vijayakumaran, R. (2019). Corporate governance and capital structure decisions: Evidence from Chinese listed companies. Journal of Asian Finance, Economics and Business, 6(3), 67-79. https://doi.org/10.13106/jafeb.2019. vol6.no3.67

Wahyuningsih, Melawati, S. E. (2016). The Influence of Good Corporate Governance, CSR, and Company Size on Company Performance (Indonesian). Journal of Economic and Economic Education, 4(2). https://doi.org/http://dx.doi.org/10.22202/ economica.2016.v4.i2.380 